\title{
SNCAIP Gene
}

National Cancer Institute

\section{Source}

National Cancer Institute. SNCAIP Gene. NCI Thesaurus. Code C102936.

This gene is involved in the modulation of ubiquitination. 